Please do not remove this page

RMIT

UNIVERSITY

\title{
Part-time of what? Job quality and part-time employment in the legal profession in Australia
}

Campbell, Iain; Charlesworth, Sara; Malone, Jenny

https://researchrepository.rmit.edu.au/esploro/outputs/9921858344501341/filesAndLinks?institution=61RMIT_INST\&index=null

Campbell, I., Charlesworth, S., \& Malone, J. (2012). Part-time of what? Job quality and part-time employment in the legal profession in Australia. Journal of Sociology, 48(2), 149-166.

https://doi.org/10.1177/1440783311408970

Document Version: Accepted Manuscript

Published Version: https://doi.org/10.1177/1440783311408970

Repository homepage: https://researchrepository.rmit.edu.au

(C) 2011 Australian Sociological Association

Downloaded On 2023/04/26 21:03:07 +1000

Please do not remove this page 
Thank you for downloading this document from the RMIT Research Repository.

The RMIT Research Repository is an open access database showcasing the research outputs of RMIT University researchers.

RMIT Research Repository: http://researchbank.rmit.edu.au/

\section{Citation:}

Campbell, I, Charlesworth, S and Malone, J 2012, 'Part-time of what? Job quality and part-time employment in the legal profession in Australia', Journal of Sociology, vol. 48, no. 2, pp. 149-166.

See this record in the RMIT Research Repository at: http://researchbank.rmit.edu.au/view/rmit:16576

Version: Accepted Manuscript

Copyright Statement: (c) 2011 Australian Sociological Association

Link to Published Version:

http://dx.doi.org/10.1177/1440783311408970

\section{PLEASE DO NOT REMOVE THIS PAGE}


Part-Time of What? Job Quality and Part-time Employment in the Legal Profession in Australia

Iain Campbell, Sara Charlesworth, Jenny Malone

\begin{abstract}
This paper examines the quality of part-time employment for solicitors in private practice in Australia. Though full-time jobs based on long hours are dominant in the legal profession, part-time jobs, primarily taken by women, have attracted attention in recent years. The paper seeks to answer fundamental questions about the extent and quality of these jobs and how well they serve the needs of the increasingly diverse workforce. The paper draws on recent surveys and in-depth interviews as well as census and other secondary data to describe the features of the part-time workforce and to explore aspects of poor quality such as limited access, inferior job content, stalled career progression and narrow schedules. It suggests that the major barrier to improving the quality of part-time jobs is the dominant model of full-time work in law firms, centred on heavy workloads, high targets of 'billable hours' and long working hours.
\end{abstract}

Keywords: part-time work, legal profession, job quality, gender, long hours. 


\section{Introduction}

Solicitors in private practice offer an intriguing case study for any research into part-time employment. At first glance, it might be thought that modern law firms would provide a positive environment for the development of what is called 'quality', or perhaps more correctly, 'good quality' part-time work (Fagan, 2004; Chalmers et al., 2005; Lyonette et al., 2010). The workforce has become increasingly diverse, with more and more women entering the legal profession and many women, together with some men, seeking opportunities for flexible work that can better reconcile paid work and the rest of life. At the same time, employee solicitors would appear to enjoy favourable conditions in the labour market. The work is highly skilled, requiring qualifications based on long periods of education and training. Moreover, in recent decades, the demand for legal services has been expanding, swelling the number of employed solicitors. Most jobs are well-paid and prestigious, and traditional concepts of professional autonomy still exercise an influence. All this would seem to suggest a strong labour market position, establishing a good starting-point for legal professionals to negotiate reduced hours to suit their needs and interests outside paid work.

This paper asks whether and to what extent these expectations about good quality part-time work in law firms are being met. It reports on a recent research project, which used official data from the Australian Bureau of Statistics (ABS), legal profession surveys, relevant case law, postings on legal blogs ('blawgs') and other secondary material, as well as a program of interviews with solicitors currently in private practice, solicitors who have left private practice and Human Resources (HR) managers in major law firms in Melbourne in the state of Victoria. 
The existing academic literature on the legal profession in Australia is relatively sparse, and it has not paid much attention to working-time arrangements, including part-time work (Williams-Wynn and Nieuwenhuysen, 1982; Weisbrot, 1990; Roach-Anleu, 1992b; Hughes, 2001). However, more recent contributions, often focused on the situation of women, have begun to look closely at the changing structure of the legal profession and have raised concerns about gendered barriers to increased flexibility and limited opportunities for good quality part-time work (Cook and Waters, 1998; Roach-Anleu, 1992a, Thornton, 1996, 2005; Hunter, 2003). One recent article examines flexible work in corporate legal practice and argues that despite the rhetoric of work/life and gender equity strategies publicly embraced by corporate firms, the reality for many women who take on part-time work is a stymied legal career (Thornton and Bagust, 2007). This concern is echoed in work undertaken by or on behalf of women lawyers' organisations, including three recent surveys undertaken in the state of Victoria (VWL, 2001; Aequus Partners, 2005; LIV \& VWL, 2006).

This paper extends the existing Australian studies by assembling new quantitative and qualitative evidence about the quality of part-time jobs in the law. It also contributes to the international literature that examines how part-time work can serve the interests of work-life balance (Fagan, 2004; Warren, 2004). It provides a case study of one important area of professional work, arguing that the opportunities for better work-life balance are hampered by fundamental trends in the structure of the industry.

The first section of the paper sketches out the industry context in Australia then turns to official ABS data to outline the working hours of solicitors, including the proportion engaged in part-time work. The second section introduces the main components of our study. The 
third section uses the empirical material in order to examine the quality of the part-time jobs, focusing on the concerns that have been raised about limited access to part-time jobs, inferior job content, stalled career progression, and a narrow range of schedules. This section asks: how well do part-time jobs in the law meet the needs of an increasingly diverse workforce? The final section focuses on the barriers to improving quality, suggesting that the narrow and constrained schedules of part-time jobs reflect the influence of the model of full-time work that has become dominant in most law firms.

\section{The Australian legal profession}

\section{The work of solicitors}

The structure of the legal profession in Australia is closely related to the United Kingdom model, though it has also been influenced by the United States (Hughes, 2001). The legal profession in Australia is now formally fused in many jurisdictions, but a de facto distinction between solicitors and barristers survives in one form or another. According to one textbook (Hughes, 2001: 277):

The term 'solicitor' generally refers to a person who specialises in legal work other than advocacy work, at least advocacy work in the superior courts... Solicitors are those legal practitioners who commonly: prepare matters for trial or hearing; carry out conveyancing work; handle corporate matters; administer deceased and bankrupt estates; and provide advice of a general nature. 
Solicitors are the dominant occupational group in the legal profession. Although some practising solicitors work as in-house counsel for large corporations or public sector departments, and a small number work in legal aid or community legal centres, the vast majority work in private solicitor practices, which bring together solicitors with administrative staff and paralegals. It is this majority segment of the profession working in private practice that is the focus of this paper. Private practices are usually organised as partnerships, although recent legislative change permitting incorporation has produced a few incorporated entities (ABS, 2009). The partnership structure can be varied, allowing different sizes from single-partner firms to large, national firms with over one hundred partners and over one thousand employees.

Solicitors provide legal services to clients, who can be individuals or firms. Even in large law firms, solicitors often work directly with clients, either individually or as members of a small team. The income of solicitors in private practice, whether they are proprietors/ partners or employees, ultimately derives from the income (and profit) that is achieved by means of fees received from clients for the provision of these legal services. The fee structure varies, but most firms rely on a system based on billable hours, in which the bill for the client is composed by recording the hours of the solicitors working on a file and then multiplying by an hourly charge-out rate appropriate to the seniority and experience of the contributing solicitors.

Traditionally, the legal profession in Australia, as elsewhere, has been organised around a gendered norm of the 'unencumbered' or 'ideal' worker (Williams, 2000). Work was structured around the notion of the male breadwinner who was available to work across a wide range of hours, supported by a female partner responsible for caring and domestic 
duties. For many centuries women were formally barred from participation at any level in the legal profession. Entry into legal training was traditionally understood as entry by men into a life-time career that would end in partnership within a small practice, and the workplace culture in these small firms acquired a distinctly masculine cast, described in terms of homosociality (Thornton, 1996).

Two major changes in Australia, as in many other countries, have occurred over the past two decades - the rise of medium and large law firms (Thornton, 2005) and the feminization of the legal profession workforce (Thornton, 1996; Thornton and Bagust, 2007; Hunter, 2003). Together, the two trends have contributed to a shift in the profile of the typical solicitor. The rise of larger firms means that most solicitors ${ }^{1}-$ a total of three quarters according to 2006 Census data - now work as employees rather than as self-employed (see Table 1). At the same time, the proportion of women has been steadily increasing, and they now constitute 42 per cent of all solicitors, both employees and self-employed. Nevertheless, in spite of the steady increase in female participation, women have failed to progress along the career path within firms at the same rate as men. They remain concentrated at lower levels and continue to be poorly represented at the level of partner or principal in the large firms (Hunter, 2003). Table 1 suggests that although women constituted well over half of solicitors classified as employees in 2006, they accounted for only 17 per cent of those classified as non-employees (the category covering principals or partners in law firms).

\section{Table 1 about here}


That women are not more highly represented in the upper echelons of the profession cannot be explained as a lag effect, attributable to the relative novelty of female participation. It is likely that women have constituted the majority of law students and law graduates in Australian universities for more than twenty years (Hunter, 2003: 100; VWL, 2005: 4-5). As Hunter notes (2003: 95), the lack of representation can be attributed both to a higher drop-out rate for women compared to men and to slower advancement for the women who remain. This in turn draws attention to a further labour market change, though one that is harder to identify in the official statistics - the erosion of the pattern of a life-long career in law firms, marked by steady progress towards partnership. This pattern now applies to just a minority of new entrants. Law firms are increasingly characterised by high turnover rates, as many young lawyers, especially women but also many men, leave these firms only a few years after entry. They are in turn replaced by the next cohort of highly skilled and highly motivated graduates (LIV and VWL, 2006: 3; IBISWorld, 2007: 45; James, 2008).

\section{Part-time work}

Jobs with reduced hours have become widely available in most parts of the employment structure in Australia, and indeed Australia now stands third in current OECD rankings for the incidence of part-time employment (OECD, 2010: 287; see Abhayaratna et al., 2008). This has helped to spark interest in the idea of 'quality' part-time work (Chalmers et al., 2005; Bardoel et al., 2007). However, available statistics suggest that a trend to more parttime jobs is not readily evident in the legal profession. Though the number of part-time solicitors has increased over past decades, the proportion remains small. In the 2006 Census, 11.8 percent of solicitors, predominantly women, stated that they worked between one and 34 hours during the reference week (ABS, 2006). The proportion is likely to be less amongst 
solicitors in private practice. A survey conducted by The Australian newspaper of thirteen of the largest law firms in late 2010 suggested that 9.6 per cent of lawyers at these firms were employed part-time (Berkovic, 2010). But this figure is likely to be too high, since the definition of 'part-time' is laid down by the firms themselves and may include some solicitors working more than 35 hours per week.

\section{Full-time work: the dominance of long working hours}

The dominant form of work amongst Australian solicitors, both for men and for the increasing number of women in the profession, remains full-time work. This is in turn based on long daily and weekly hours of work. Solicitors appear to stand out, even amongst professional and managerial groups, for the number of hours they work (ABS, 2006). Thus, in 2006, almost half (45.1 per cent) of all solicitors reported working 49 or more hours in the reference week. This figure is influenced by the presence of a significant minority of selfemployed solicitors; however, even if we focus just on solicitors who are employees the proportion that reported working 49 or more hours was substantial (38.6 per cent) (ABS, 2006).

Female solicitors are less likely than male solicitors to work very long hours, but the proportion is still high. Figure 1 shows the similar pattern for male and female employee solicitors.

\section{Figure 1 about here}


Long working hours are common for solicitors in private practice. The rhythm of full-time work varies somewhat according to the different areas of practice, but all areas involve long hours. Data from interviews and other sources suggest that the long hours are in the first place long daily hours on weekdays, generally spent at or around the workplace, but such schedules readily spill over into work at the weekend or work at home in the evenings. Public holidays or periods of annual leave may also offer occasions for extra work. In most areas of practice, long hours can be further extended with little predictability and often at short notice, in response to demands from supervisors, other members of the team, courts, clients or opposing legal teams. It is true that solicitors enjoy some flexibility at the margins, for example to influence the location of work (work at home on weekends or evenings) and the distribution over the day and week (delayed start and finishing times). But this ad hoc flexibility occurs within a basic temporal structure that is surprisingly uniform, characterised by strong pressures towards long working hours.

In a recent survey of employed solicitors in Victoria the majority (64 per cent) of respondents estimated the daily hours of full-time lawyers, excluding breaks, as nine to ten hours. They also pointed to a practice of regularly working through lunch breaks, sometimes working during the weekends and sometimes taking work home (LIV \& VWL, 2006: 11, 31). This pattern of long hours in a full-time job is not impeded by formal working-time regulation, which is relatively lax in Australia (Campbell, 2007: 51-57), and it appears to have become a norm in private practice.

A range of explanations for this demanding and rather inflexible pattern of full-time work are commonly offered, assigning the main responsibility either to the employer, the individual 
employee or indeed the clients. A detailed examination of these is beyond the scope of this paper. However, we can note that many employees in law firms feel pressured by high workloads and they often cite the system of billable hours as at least the proximate cause of their long hours (James, 2008). Initially just a technique for billing clients, what is known as 'billable hours' has been transformed into a tool for managing and controlling the work of employee solicitors, in particular through the imposition of high targets, close time recording and careful monitoring of the performance of work (Campbell et al., 2008). In Australia targets are framed in terms of the day. It is estimated that three quarters of private practice solicitors have a billable hours target of six to seven hours per day (IBISWorld, 2007: 44), with larger firms generally demanding more than seven hours (VWL, 2005: 6-7). This implies, with added administration and other tasks, actual working hours of ten to twelve per day.

\section{Investigating the quality of part-time jobs}

Our framework for assessing job quality in part-time jobs is detailed in an earlier paper (Chalmers et al., 2005). We start from a worker-centred perspective, which understands job quality as constituted by 'the set of work features which foster the wellbeing of the worker' (Green 2006: 9). In this framework, approaches to part-time jobs should be similar to that for

full-time jobs, though working-time dimensions are more important in the former case and the need to wrestle with the diversity of both schedules and individual needs is generally more pressing. 
Though job quality is best seen as to do with objective features of the job, comprehensive data on all relevant features are rarely available in large-scale surveys. It is necessary to supplement quantitative indicators by drawing on the perspectives of the workers themselves, both in order to document the more elusive features of the job and to investigate the subjective impact of these features.

To explore in more detail the working-time patterns of solicitors in private practice, with a special focus on the quality of part-time work, we used results from recent surveys in Victoria (Aequus Partners, 2005; LIV and VWL, 2006) as a platform for a dedicated program of indepth interviews. The interview program was designed to elicit views from a range of persons associated with law firms. The interviews included one focus group with eight solicitors working part-time, organised by the Law Institute of Victoria’s Part-time Lawyers’ Network, as well as individual interviews with a further 27 persons: fourteen solicitors currently employed in law firms (including one on secondment and another on maternity leave), nine solicitors who had left law firms within the past ten years, and four HR managers in large law firms. Sixteen of those who took part in the focus group and interviews either worked now or had worked previously as part-time solicitors. The HR managers were interviewed as a result of written approaches to four firms, but the other individual interviewees were located using an opportunistic snowball technique where interviewees or other informants identified other potential interviewees. Most were employees or ex-employees, but in order to broaden the range of views we also included four partners or principals. The focus group included one man, and we interviewed individually four other men currently practising as solicitors in law firms, but the majority of interviewees were women, reflecting our particular interest in parttime work. 
The individual interviews were conducted in 2007 and 2008 using a semi-structured interview schedule. The focus group and interviews were audio-taped and transcribed. The transcripts were analysed to identify key issues around the organisation and practice of working time, and the interviewees were assigned pseudonyms to protect privacy. Although not constituting a representative sample, the focus group and interviews are valuable in revealing the lived experience of working-time arrangements, in generating questions for examination with other methods, and in helping to refine theories about the construction of part-time jobs in legal firms.

\section{The quality of part-time jobs for solicitors}

Many features of legal work are attractive and can be found in part-time as well as full-time jobs. One oft-cited feature is the challenging nature of much legal work. Perhaps the most prominent positive feature is the high salary earned by many solicitors, especially in the larger commercially-oriented firms. Part-time solicitors are not excluded from these high salaries and they generally enjoy pro rata entitlements (although they may lose access to bonuses and may have limited prospects of access to the higher rewards of partnership). Helen, a part-time solicitor, explicitly drew attention to the issue of pay:

(T)he good thing about being a lawyer is the money that I earn. If I wasn't a lawyer I'd probably have to work full-time to earn that sort of money... in another area. So that if I can work part-time, you know, three days a week, and have two days with my family, that means a lot to me, and it's not such a huge trade off because you know, I am paid well... Some of my girlfriends who might be in retail, they'd have to work six days a week to earn that sort of money. 
However, data both from the industry surveys and from our interviews indicate that four aspects of part-time jobs for solicitors are of concern. The first - consistent with the census data on the relatively small proportion of part-time jobs - is limited access, whereby only workers who meet a forbidding range of preconditions are able to secure a position with reduced hours. For those who succeed in obtaining a part-time position, the substantive features of the job can cause further concern and discontent. Problems of inferior job content and stalled careers are familiar from other professional and semi-professional contexts in Australia (Charlesworth and Whittenbury, 2007; McDonald et al., 2009). But less familiar and more distinctive to the legal profession is the issue of a narrow range of schedules. In this section, we illustrate each of these four problems, before attempting to sum up how they affect job quality and the experience of work.

\section{Limited access}

Practical access to part-time work in law firms is limited. The usual means of access to a parttime schedule is when an existing full-time employee requests a change to part-time work. The majority of requests for reduced hours come from women and are related to care-giving responsibilities, often in connection with return from a period of maternity leave (LIV and VWL, 2006: 9, 34).

Making a request for reduced hours does not guarantee a positive response. Responses are largely dependent on the grace and favour of the supervisor. Although most firms have policies in place regarding a range of 'flexible' work options, these generally leave extensive room for supervisor discretion, and the processes of responding to a request for part-time 
work can vary widely. Amanda, an HR Manager, described one firm-level process in a way that hints at some of the obstacles, including the dependence on managerial discretion and the possibility of losing one's current position. She suggested that if an employee wished to reduce his or her hours:

They would immediately approach their practice group leader... and speak to them and say: "If the needs of the business are able to be met, can I please work part-time?" We have got computer equipment available for people to work from home if they need to... Once that negotiation side of thing's taken place, then the practice group leader would say: "Okay, yes... the area of law that we do is conducive to part-time work, or maybe we'll move you into somewhere else”... And then it sort of goes up the tree and approval from the national practice group leader would then be obtained.

From the point of view of the employer, part-time work is seen mainly as an issue of retention, as a concession offered to favoured employees. Flexible work policies are applied on an ad hoc basis dependent on factors such as the perceived legitimacy of the reason for the request, the performance and therefore value of the employee, the warmth of the relationship between the employee and the supervising partner, the promises made by the employee concerning their performance during the period of part-time work, and the prospects of the employee eventually returning to work full-time. According to Amanda, a favourable response to a request for part-time work depends above all on what she terms 'longevity' - 'if we believe that they're here for the long haul...' In this approach, a key criterion is whether the move to part-time is just temporary and the employee can be expected to revert at some point to a standard full-time job. 
Not all requests are granted. Several interviewees had been able to obtain part-time work, but others testified to experiences of rejection:

I wanted to work part-time, but that was not allowed. Then I asked if I could work one day a week from home and the response I got was pretty average... I just got asked how that they could guarantee that I wouldn’t be doing the cooking, washing, ironing and cleaning on that day. (Sharon)

\section{Inferior job content}

Much evidence suggests that the move to part-time work in legal practice can result in the allocation of work that differs from the work associated with the previous full-time position. A key finding of one 2005 survey was that 74 per cent of lawyers surveyed 'perceive that the type or quality of work changed after they started working flexibly', with more than two thirds of this group viewing the change as negative and unwanted. One survey respondent described her new work as 'filling gaps' and working as a 'helper' who 'tended not to be in charge of things' (Aequus Partners, 2005: 28-29).

Sometimes solicitors are shifted to entirely different areas of practice when they become parttime, in line with views held by the decision-makers within legal firms as to the appropriateness or otherwise of certain areas of practice for part-time work (Aequus Partners, 2005). This issue was highlighted in the 1998 Hickie $v$ Hunt \& Hunt decision by the Human Rights and Equal Opportunity Commission. Marea Hickie, a solicitor and contract partner in a law firm, was grudgingly allowed to work part-time when she returned from maternity leave. However, the company removed her plaintiff practice while she was on maternity leave on the basis that she intended to work part-time on her return and could not manage 
such a large practice without supporting staff, thereby stripping her completely of the practice she had built up over several years. The Commission found that Hunt \& Hunt had indirectly discriminated against Ms Hickie by requiring in effect that she work full-time to maintain her position (HREOCA, 1998).

Similar concerns that solicitors are given less interesting and less responsible jobs when they move to a part-time schedule were often raised by our interviewees. For example, Fiona, a part-time solicitor, complained about:

loss of responsibility and control of matters... I'm only sort of second-in-command and therefore don't have the relationship with the client...That could be frustrating and it could also affect your career development.

\section{Stalled career progression}

It is frequently noted that moving to part-time work in the law, as in other occupations, can dash hopes of career progression. This is partly linked to the issue of inferior job content. Findings from a 2005 survey (LIV and VWL, 2006) point to the career consequences of not undertaking face-to-face work with clients or 'high profile' work or not being given any new referrals or any new substantive work. The more interesting and responsible work, crucial for learning and career progression, was seen as falling to full-time solicitors who were identified as on a clear partnership track.

As Beth, a part-time solicitor on maternity leave, put it:

Basically I think if you want to be a part-time partner you've got to get to partnership first and then once you've got the contacts and the clients then you can dictate your own terms, 
but coming as a junior and then moving to working part-time all the way through, I think it is pretty impossible.

A broader problem here is the common view amongst supervisors that part-time solicitors have stepped off the career path, or, at best, are delaying this decision (LIV and VWL, 2006: 35). There is a widespread assumption that those who choose to go part-time have effectively ‘chosen’ family over work and are uninterested in furthering their career. Even if part-time employees clearly express a desire to continue on the track to partnership, they may still be perceived by others as less committed, as they are less visible. This represents part of the stigma of part-time work (Epstein et al., 1999); one of several discriminatory myths about part-time workers in the law (Williams and Calvert, 2002).

\section{Narrow range of schedules}

One further source of discontent seems more peculiar to part-time work in law firms. This concerns the nature of the part-time schedules available to workers. Part-time jobs in private practice seem to come in just one size. Most part-time solicitors work in a schedule that is framed in terms of a minimum number of days per week - usually four but sometimes three or three-and-a-half days (LIV and VWL, 2006: 34). Each workday, as in the case of full-time solicitors, involves a fluid number of actual hours, but these hours invariably tend to be long, or very long, often ten or more. Indeed, the hours can be so long that they challenge the conventional definition of 'part-time'. When solicitors are working four days a week and ten hours a day, the total number of weekly hours stretches up to and beyond the normal threshold of 'full-time' work. It only appears reduced when compared with the even longer hours of full-time solicitors in law firms. 
When examined closely, such schedules can appear even narrower and more constrained than at first sight. The schedules offer a limited flexibility for the employees, but they are associated with high levels of flexibility for the employer. The boundary between work and non-work is porous, with employees enjoying little control. Thus many part-time workers are expected to work or be available for work even on days that are supposedly reserved for their own needs and supposedly free of obligations to the employer. The dynamics behind these expectations are complex. Often the extent of flexibility has been negotiated as a condition of the move to part-time work. Or it can be freely offered by the employee, appreciative of the opportunity to work fewer hours, committed to the firm or the project team and perhaps conscious of the difficulty of obtaining reduced hours in the profession. Cathy, an HR manager, suggested that part-time workers are happy to offer flexibility:

Generally people are very committed to what they do, and they all say: "Look can we have a BlackBerry?” And they're always happy to return phone calls to clients if it's an emergency.

In the main the part-time solicitors that we spoke to were positive about their work. They were conscious of the limited access to reduced hours. They were often aware that their position was dependent on a highly personalised process of evaluation and that they might not have secured this opportunity from another firm. They seemed to accept the need to offer a high degree of flexibility to their employer as a necessary part of the informal exchange. Often the quite extreme levels of flexibility that they offered emerged only in the interstices of the interview:

Where I work... they're quite reasonable... I rarely work outside my allotted three days. I'm working at the moment on a trademarks hearing, and I did work this weekend when I 
took the work home... And I do make myself available for calls on my days off. I mean, of course, sometimes I'm doing things that you can't contact me, but I'm more than happy to talk to people over the phone and look at things that they email through to me... (Sharon)

Similarly, Helen, a part-time solicitor working three days a week, described how she had asked to be employed as a 'casual', so that she could take days off if her child was sick without feeling that she was thereby short-changing her employer. But she still felt obliged to be available outside of her usual three days. She explained:

Well I've got those two days that are mine. I still take calls...Yep, I still take calls and if I have to do any little job or if I do have to take some work home with me, I do. Because I have to.

Rebecca, who was uneasily contemplating a return to work from maternity leave, ideally on a part-time basis, had tapped the views of her part-time colleagues:

[It] is difficult because you are there for your three days and you've still got to bill your seven and a half ... You don't have much time either side on those three days to do all of the administrative stuff and just keeping your skills up. So this woman told me, she tended to do a lot of that then at home and then after hours, because that's really the only time you've got to do it.

As Rebecca hints here, part-time and full-time jobs are subject to the same high daily targets for billable hours - in this case seven and a half billable hours per day. The difference for part-time workers is that these targets apply just to three or four days in the week rather than 
five days. In short, part-time jobs are closely modelled on and indeed attached to the basic structure of full-time jobs.

This working-time model, in which similar demands are applied to all workers, could be seen as gender-blind. Phillip, a legal firm partner, argued:

[U]ltimately, regardless of your gender... the way the system works at the moment is that there is a premium given to people who work full-time... And there's also a premium given to lawyers who are available. Not just working full-time, but if they are available to do things... I don’t think law firms are actually anti-female or anti-race or anti-marital status or anything like that. It's just ... certain parts of society are, or find it difficult to satisfy the requirements.

What Phillip describes is a new version of the norm of the 'ideal worker', who steadily works full-time hours, leaves caring responsibilities at the office or factory door, and stands ready and available, often at short notice, for additional hours at the behest of the employer. Such a norm may appear gender-blind, but it presupposes that caring responsibilities are not taken on by the 'ideal worker' but are instead shuffled off to others. This 'ideal worker' norm inevitably discriminates indirectly against women, who - quite apart from any issue of needs and interests - have less capacity to outsource caring responsibilities, especially for small children. Moreover, it often leads to direct discrimination, in which the failure of many women to conform to the ideal worker norm is the platform for discriminatory attitudes and behaviour that reach beyond women with children to encompass all women.

\section{Part-time job quality in legal practice}


In sum, in spite of several positive characteristics such as interesting work and high pay, parttime jobs in the legal profession often display negative features that detract from job quality. Difficulties such as inferior job content and stalled career progression are a familiar source of frustration to part-time workers in a wide range of professional occupations. In addition, the surveys and interviews point to difficulties associated with the distinctive working-time arrangements of solicitors in private practice. A central issue here is the narrowness of parttime schedules, centred on long daily hours over three or four days a week, with extra hours often spilling over into the remaining days in the week. These schedules seem just as demanding and inflexible as the full-time schedule, and they thereby constitute a significant problem for workers seeking reduced hours. Even if a worker is fortunate enough to secure a part-time job, there is little guarantee that such narrow schedules will meet his or her needs. Such schedules do not fit for example with those who want shorter daily hours, for example to drop off and pick up children from school. Nor do they fit well with those who want to fit their working hours around a part-time course and lecture and exam times.

If solicitors desire a better, more flexible range of part-time schedules, they must leave the private law firms, perhaps to move into corporations or into government departments as inhouse counsel, or perhaps to move out of the law altogether. Several interviewees in our study had trodden these well-worn paths, largely in response to unsatisfactory working-time patterns, either after a few years of full-time work or after a spell of part-time work in law firms.

\section{Conclusion: barriers to quality part-time work}


The assumption that law firms in Australia provide a positive environment for quality parttime work is questioned in this paper. Our evidence and analysis supports a different, more negative conclusion. One factor here concerns labour market conditions, which are far less favourable in practice than they may appear at first glance. We refer above to the abundant supply of graduates spilling out every year from law schools. This oversupply of solicitors sustains poor working-time conditions and high turnover rates in most medium to large law firms, functioning to damp down any threat posed by dissatisfaction and 'burn out'.

However, it is necessary to dig deeper if we want to identify the specific barriers to good quality part-time jobs in law firms. Some scholars point to the evidence of entrenched conservatism and discriminatory attitudes towards women. This could be linked to the persistence of traditional attitudes and behaviours, and hope could be vested in generational change or perhaps the formulation and dissemination of a solid 'business case' for better treatment of employee solicitors (Thornton and Bagust, 2007; Williams, 2007). However, our study suggests that the most immediate barrier lies elsewhere. We argue that a central difficulty for part-time workers in the legal profession concerns the narrow range of part-time schedules, and we suggest that this in turn reflects the influence of a dominant model of fulltime work, structured around high workloads and high targets for billable hours. Part-time jobs clearly stand under the long shadow of this model of full-time work. They have been reluctantly fitted on to this model and made subject to similar performance requirements, though it is clear that they do not fit easily or well. Thus, it is not surprising that part-time jobs are still relatively few and marked by features of poor quality. As Rubery et al. (2005) note, it is difficult to create good quality part-time jobs when the hours standard associated with full-time work is fluid and stretches out into very long daily, weekly and annual hours. The question becomes: part-time of what? 
In this line of argument, it is not so much traditional attitudes but rather modern economic structures that should be seen as the main source of the difficulties and discrimination faced by workers seeking a better work-life balance in the legal profession (see also Sommerlad 2002; Bolton and Muzio 2007). The major barrier is the dominant model of full-time work. Though this dominant model resembles older models, it is largely the product of new developments, derived from the rise of medium and large law firms and the spread of a specific business model aimed at maximising profitability through increased leverage of employees. The model is firmly anchored in new management practices, including billable hours targets, and it pivots on a reconfigured version of the 'ideal worker' in which new and more stringent demands are placed on full-time workers. Under this model, which at a societal level is usefully described as an 'adult worker' model (Lewis, 2002), women are indeed incorporated into the profession but only on narrow terms, in which they are allowed to seek to measure up to the reconfigured norm of the ideal worker, void of external ties and freely available to the employing organization.

\section{Notes}

${ }^{1}$ In the ABS classification scheme, solicitors (ANZSCO 2713) are defined as persons who “provide legal advice, prepare and draft legal documents, and conduct negotiations on behalf of clients on matters associated with the law” (ABS, 2005). 


\section{Acknowledgements}

This research was supported under the Discovery Projects funding scheme of the Australian

Research Council (DP 0449771). Many thanks to the interviewees who participated in the

project and thanks to Estelle Tang, who conducted most of the individual interviews.

\section{References}

Abhayaratna, J., L. Andrews, H. Nuch and T. Podbury (2008) Part Time Employment: the Australian experience, Staff Working Paper, The Productivity Commission.

ABS [Australian Bureau of Statistics] (2005) Information Paper: ANZSCO - Australian and New Zealand Standard Classification of Occupations, 2005, cat. no. 1221.0.

ABS (2006) Australian Census 2006, customised data supplied on request.

ABS (2009) Legal Services, Australia, 2007-08, cat. no. 8667.0.

Aequus Partners (2005) A $360^{\circ}$ Review: Flexible Work Practices. Confronting myths and realities in the legal profession. Melbourne: Victorian Women Lawyers.

Bardoel, A., L. Morgan and C. Santos (2007) '"Quality” part-time work in Australian organizations: implications for HRD', Human Resource Development International 10 (3): 281-299.

Berkovic, N. (2010) 'Rebound sees return to full-time', The Australian, 5 November.

Bolton, S. and D. Muzio (2007) 'Can't Live with 'Em; Can't Live without 'Em: Gendered Segmentation in the Legal Profession', Sociology 41 (1): 47-64.

Campbell, I. (2007) 'Long Working Hours in Australia: Working-Time Regulation and Employer Pressures’, Economic and Labour Relations Review 17 (2): 37-68.

Campbell, I., J. Malone and S. Charlesworth (2008) '”The Overseers Have Become Crueller”: Solicitors and Billable Hours', pp. 61-70 in P. Stanton and S. Young (eds.) Workers, Corporations, and Community, Proceedings of the $22^{\text {nd }}$ Conference of AIRAANZ, volume 2. Melbourne: AIRAANZ.

Chalmers, J., I. Campbell and S. Charlesworth (2005) 'Part-time Work and Caring Responsibilities in Australia: Towards an Assessment of Job Quality', Labour and Industry 15 (3): 41-66.

Charlesworth, S. and K. Whittenbury (2007) '”Part-time and part-committed"?: The Challenges of Part-time Work in Policing', Journal of Industrial Relations 49 (1): 31-47.

Cook, C. and M. Waters (1998) 'The impact of organizational form on gendered labour markets in engineering and law', The Sociological Review 46 (2): 314-339.

Epstein, C., C. Seron, B. Oglesky and R. Sante (1999) The Part-Time Paradox: Time Norms, Professional Lives, Family and Gender. New York: Routledge.

Fagan, C. (2004) 'Gender and working time in industrialized countries', pp. 108-146 in J. Messenger (ed.) Working Time and Workers' Preferences in Industrialized Countries: Finding the Balance. London and New York: Routledge.

Green, F. (2006) Demanding Work: The Paradox of Job Quality in the Affluent Economy. Princeton: Princeton University Press.

HREOCA [Human Rights and Equal Opportunity Commission of Australia] Hickie v Hunt \& Hunt [1998] (Justice Elizabeth Evert, 9 March 1998), digest reported (1999) EOC 92910.

Hughes, R. (2001) Australian Legal Institutions: Principles, Structure and Organisation. Sydney: Law Book Company. 
Hunter, R. (2003) 'Women in the Legal Profession: The Australian Profile', pp. 87-102 in U. Schultz and G. Shaw (eds.) Women in the World's Legal Professions. Oxford: Hart Publishing.

IBISWorld (2007) Legal Services in Australia: L7841, IBISWorld Industry Report, October.

James, C. (2008) 'Lawyer dissatisfaction, emotional intelligence and clinical legal education', Legal Education Review 18: 123-137.

Lewis, J. (2001) 'The Decline of the Male Breadwinner Model: Implications for Work and Care', Social Politics 8 (2): 152-169.

LIV \& VWL [Law Institute of Victoria and Victorian Women Lawyers] (2006) Bendable or expendable? Practices and attitudes towards work flexibility in Victoria's biggest legal employers. Melbourne: LIV and VWL.

Lyonette, C., B. Baldauf and H. Behle (2010) "Quality" part-time work: a review of the evidence. London: Government Equalities Office.

McDonald, P., L. Bradley and K. Brown (2009) "'Full-time is a Given Here": Part-time versus Full-time Job Quality’, British Journal of Management 20 (2): 143-157.

OECD (2010) 'Statistical Annex', pp. 267-305 in OECD Employment Outlook 2010. Paris: OECD Publishing.

Roach Anleu, S. (1992a) 'Women in the Legal Profession: Theory, Research, and Practice', Australian and New Zealand Journal of Sociology 28 (3): 391-410.

Roach-Anleu, S. (1992b) 'The Legal Profession in the United States and Australia: Deprofessionalization or Reorganization?', Work and Occupations 19 (2): 184-204.

Rubery, J., Ward, K. and Grimshaw, D. (2005) 'The Changing Employment Relationship and the Implications for Quality Part-time Work', Labour and Industry 15 (3): 7-28.

Sommerlad, H. (2002) 'Women solicitors in a fractured profession: intersections of gender and professionalism in England and Wales', International Journal of the Legal Profession, 9 (3): 213-234.

Thornton, M. (1996) Dissonance and Distrust: Women in the Legal Profession. Melbourne: Oxford University Press.

Thornton, M. (2005) 'The Australian Legal Profession: Towards a National Identity', pp. 133-169 in W. Felstiner (ed.) Reorganisation and Resistance: Legal Professions Confront a Changing World. Portland: Hart.

Thornton, M. and Bagust, J. (2007) 'The Gender Trap: Flexible Work in Corporate Legal Practice’, Osgoode Hall Law Journal 45 (4): 774-811.

VWL [Victorian Women Lawyers] (2001) A Snapshot of Employment Practices 2001: A Survey of Victorian Law Firms. Melbourne: VWL.

VWL [Victorian Women Lawyers] (2005) Submission to the Human Rights and Equal Opportunity Commission on its Discussion Paper, Striking the Balance: Women, Men, Work and Family. Melbourne: VWL.

Warren, T. (2004) 'Working part-time: achieving a successful work-life balance?', British Journal of Sociology 55 (1): 99-122.

Weisbrot, D. (1990) Australian Lawyers. Melbourne: Longman Cheshire.

Williams, J. (2000) Unbending Gender: Why Family and Work Conflict and What to do about it. New York: Oxford University Press.

Williams, J. (2007) 'The Politics of Time in the Legal Profession', University of St. Thomas Law Journal 4 (3): 379-404.

Williams, J. and C. Calvert (2002) 'Balanced Hours: Effective Part-Time Policies for Washington Law Firms: The Project for Attorney Retention’, William and Mary Journal of Women and the Law 8 (3): 357-442. 
Williams-Wynn, M. and J. Nieuwenhuysen (1982) 'The Legal Profession', pp. 91-122 in R. Blandy and S. Richardson (eds.) How Labour Markets Work: Case Studies in Adjustment. Melbourne: Longman-Cheshire. 
Tables and figures

Table 1: Solicitors, by employment type, by sex, 2006

\begin{tabular}{|l|l|l|l|}
\hline & Male & Female & Total \\
\hline $\begin{array}{l}\text { Employee not owning } \\
\text { business }\end{array}$ & 10982 & 13267 & 24249 \\
\hline Non-employee a) & 10350 & 2065 & 12415 \\
\hline & & & \\
\hline Total b) & 21414 & 15392 & 36806 \\
\hline
\end{tabular}

Source: ABS 2006.

a) comprises 'owner-managers of incorporated enterprises', 'owner-managers of unincorporated enterprises' and 'contributing family workers'

b) includes 'not stated' 
Figure 1: Solicitors, employees not owning business, distribution of actual weekly hours, by sex, 2006

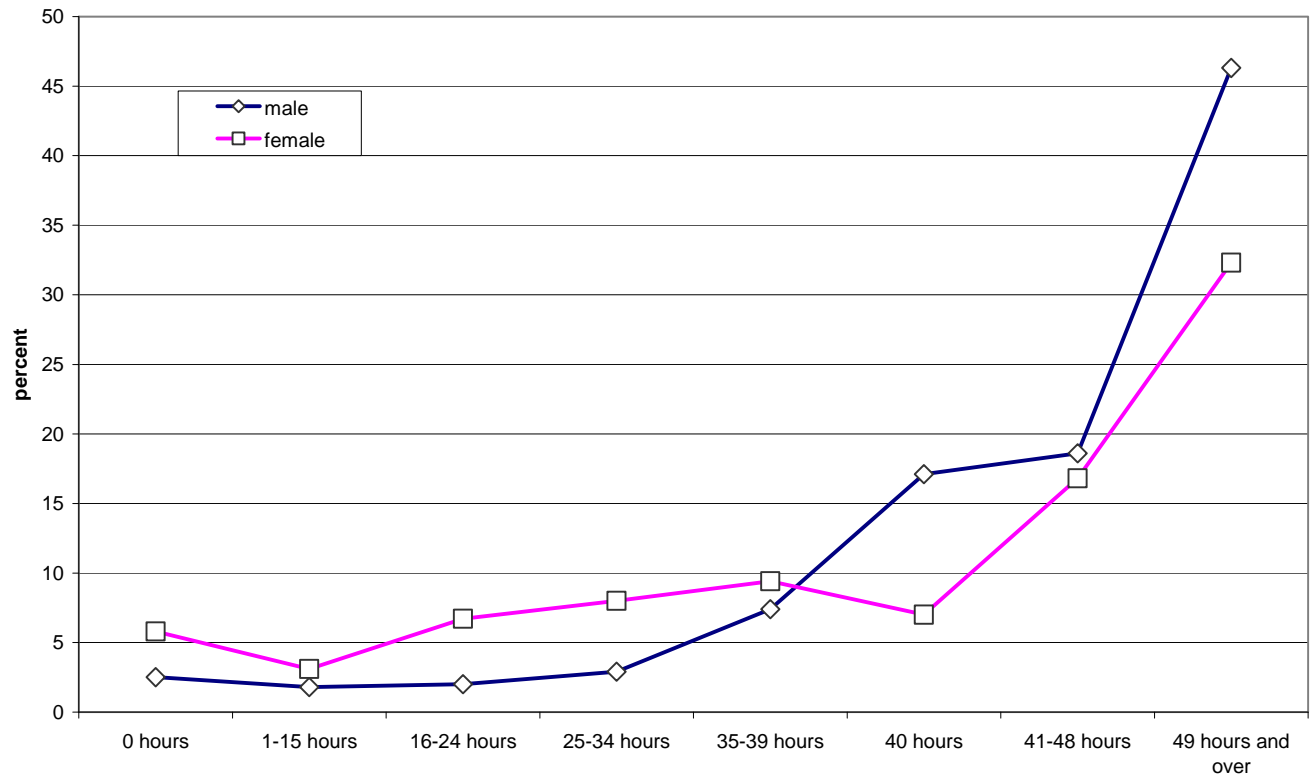

Source: ABS 2006 